Drayson, K, Wood, G and Thompson, S

An evaluation of ecological impact assessment procedural effectiveness over time.

Drayson, K, Wood, G and Thompson, S (2017) An evaluation of ecological impact assessment procedural effectiveness over time. Environmental Science and Policy, 70 (). pp. 54-66.

doi: 10.1016/j.envsci.2017.01.003

This version is available: https://radar.brookes.ac.uk/radar/items/161e7427-91c7-453f-82b3-6449987b2b3f/1/

Available on RADAR: February 2017

Copyright (C) and Moral Rights are retained by the author(s) and/ or other copyright owners. A copy can be downloaded for personal non-commercial research or study, without prior permission or charge. This item cannot be reproduced or quoted extensively from without first obtaining permission in writing from the copyright holder(s). The content must not be changed in any way or sold commercially in any format or medium without the formal permission of the copyright holders.

This document is the post print version of the journal article. Some differences between the published version and this version may remain and you are advised to consult the published version if you wish to cite from it. 


\section{An evaluation of ecological impact assessment procedural effectiveness over time}

Environmental Science \& Policy 70 (2017), 54-66

Accepted: 16 January 2017

http://dx.doi.org/10.1016/j.envsci.2017.01.003

Dr. Katherine Drayson (corresponding author) ${ }^{\text {a1 }}$

Dr. Graham Wood

Prof. Stewart Thompson ${ }^{\text {a }}$

a Department of Biological and Medical Sciences, Faculty of Health and Life Sciences, Oxford Brookes University, Gipsy Lane, Oxford, United Kingdom, OX3 OBP

${ }^{\mathrm{b}}$ School of the Built Environment, Faculty of Technology, Design and Environment, Oxford Brookes University, Gipsy Lane, Oxford, United Kingdom, OX3 OBP

katherinedrayson@aol.co.uk, +44 (0)7837877 714

gjwood@brookes.ac.uk,+44 (0) 1865483942

sthompson@brookes.ac.uk, +44 (0)1865 483253

\footnotetext{
${ }^{1}$ Currently at the Greater London Authority, City Hall, The Queen's Walk, SE1 2AA
} 


\section{ABSTRACT}

Environmental Impact Assessment (EIA) is an important tool to help decision-makers balance the environmental impacts of a proposed built development with its potential economic benefits. Used in most countries across the globe, ElA commonly includes an ecological component (Ecological Impact Assessment, or EclA). However, despite considerable changes in relevant legislation, policy and guidance, there has been no recent review of UK EcIA chapter content, with the latest review having been published in 2000 .

This study attempts to determine the procedural effectiveness of EclA chapters over time by comparing a new review of 112 English EclA chapters from 2000 onwards with earlier reviews. This was achieved through the novel use of inferential statistics, an approach previously lacking in the EIA and EcIA review literature.

The limitations and advantages of the use of quantitative methods are discussed. In general, there has been an improvement in the information content of EclA chapters over time, for example in the percentage of EclA chapters stating the size of the development and estimating the likely effectiveness of proposed mitigation measures. However, the earlier reviews highlighted such severe information deficiencies that the progress seen in the post-2000 EclA chapter review still leaves considerable scope for improvement.

Changes in the EU's EIA Directive in force since May 2014 (and to be transposed into Member State legislation by May 2017) have the potential to encourage the use of inferential statistics in EIA and EcIA review: the requirement for Member States to provide central access to EIA information should enable representative samples to be analysed.

\section{KEYWORDS}

Biodiversity, Ecology, Impact Assessment, Review, Environmental Statement, EIA 


\section{Introduction}

Across the globe, biodiversity is being lost at unprecedented rates (Millennium Ecosystem Assessment, 2005; RSPB, 2016) and international targets to slow or halt this loss have not been met (Butchart et al., 2010). A key cause of biodiversity loss is land use change (Millennium Ecosystem Assessment, 2005). In England, as across much of the inhabited world, the main drivers of land use change include agriculture, forestry and built development (Foley et al., 2005; Land Use Consultants, 2005; Maxwell et al., 2016). Given predictions of likely population increases and the consequent need for major infrastructure creation and renewal over the next ten years (Fothergill, 2011), a focus on the built environment's impacts on ecology is of importance.

Environmental Impact Assessment (EIA) is a process referenced in the legislation of approximately 180 countries worldwide (Morgan, 2012). It allows the potential environmental impacts of a proposed built development to be assessed, prior to a planning decision being made. Depending on the outcome of the scoping exercise, ecology may form a component of an EIA.

EIA can, in theory, aid decision-making and contribute towards sustainable development (Glasson, 1994). However, the effectiveness of EIA, whether substantive or procedural, has frequently been called into question (e.g. Cashmore et al., 2004). An investigation of an aspect of substantive effectiveness of EclA (the implementation and success of habitat mitigation measures in completed EIA developments) can be found in Drayson and Thompson (2013).

Procedural effectiveness relates to whether EIA is undertaken according to "established provisions and principles" (Sadler, 1996). This paper examines the procedural effectiveness of the ecological component of EIA (Ecological Impact Assessment, or EcIA) to identify current weaknesses in practice and determine whether there have been any changes over time.

One of the simplest and most cost-effective methods of researching EIA procedure is to review the key EIA documentary output, i.e. the Environmental Statement (ES) by using a checklist (Treweek, 
1996). This method does, however, depend on being able to access all the relevant key documentary information, such as technical appendices and planning agreements. Site visits, interviews and questionnaires will provide a richer context and higher level of detail, particularly since not all of the processes and findings from undertaking the EIA are necessarily reported in the ES and its associated documents (Treweek et al., 1993). However, ES review is relatively inexpensive and less timeconsuming, allowing for examination of larger numbers of ESs and therefore providing a wider picture of practice. In addition, it allows for detailed and systematic comparisons and the identification of patterns and trends over time and between countries, for example through the use of inferential statistics. This, in turn, can provide an evidence base to help inform environmental policy and legislation. This will be particularly important in the event of the UK exiting the European Union, since there may be future changes in environmental legislation and policy, the impacts of which will require assessment against a reliable baseline.

\subsection{Previous EcIA chapter reviews}

In comparison with reviews of entire ESs, reviews of individual ES technical chapters, such as the EclA chapter, have been conducted relatively infrequently. Yet these disaggregated studies can reveal differences that would otherwise be masked by a whole-ES review. For example, socioeconomic impacts tend to be poorly considered within ESs (Glasson and Heaney, 1993) and water impact assessments tend to be less poorly conducted than ecological impact assessments (Badr et al., 2004).

There have been six main published reviews of UK EcIA chapters (see Table 1) ranging in publication year from 1992 to 2000 and reviewing EclA chapters from 1988 to 1997. All used study-specific criteria, based on legislation, policy and guidance existing at the time, making comparisons between the reviews difficult. 
Table 1. Characteristics of the six main published UK EcIA chapter reviews, in publication year order, in comparison with the current review.

\begin{tabular}{|l|c|c|c|c|c|l|}
\hline Review Authors & $\begin{array}{c}\text { Publication } \\
\text { Year }\end{array}$ & $\begin{array}{c}\text { EcIA Year } \\
\text { Range }\end{array}$ & $\begin{array}{c}\text { No. of } \\
\text { EclAs }\end{array}$ & $\begin{array}{c}\text { Geographic } \\
\text { Distribution of } \\
\text { EclAs }\end{array}$ & $\begin{array}{c}\text { Planning } \\
\text { Application } \\
\text { Status }\end{array}$ & \multicolumn{1}{|c|}{ Comments } \\
\hline $\begin{array}{l}\text { Spellerberg \& } \\
\text { Minshull }\end{array}$ & 1992 & $1988-1989$ & 45 & UK & All & N/A \\
\hline Treweek et al. & 1993 & $1989-1991$ & 37 & UK & All & $\begin{array}{l}\text { Road EclA } \\
\text { chapters only }\end{array}$ \\
\hline RSPB & 1995 & $1988-1994$ & 37 & UK & All & N/A \\
\hline Thompson et al. & 1997 & $1988-1993$ & 179 & UK & All & N/A \\
\hline $\begin{array}{l}\text { Treweek \& } \\
\text { Thompson }\end{array}$ & 1997 & $1988-1993$ & 194 & UK & All & Mitigation only \\
\hline Byron et al. & 2000 & $1993-1997$ & 40 & UK & All & $\begin{array}{l}\text { Road EclA } \\
\text { chapters only }\end{array}$ \\
\hline Current Review & N/A & $2000-2011$ & 112 & England & $\begin{array}{c}\text { Granted } \\
\text { permission }\end{array}$ & N/A \\
\hline
\end{tabular}

Of those early EclA chapter reviews, all found elements requiring considerable improvement in almost every part of the EclA process (Byron et al., 2000; RSPB, 1995; Spellerberg and Minshull, 1992; Thompson et al., 1997; Treweek and Thompson, 1997; Treweek et al., 1993). These included, for example, lack of consultation, poor baseline survey, lack of quantification (of the ecological baseline and impact predictions), inadequate cumulative impact assessment, vague mitigation measure descriptions, and low levels of commitment to mitigation and follow-up. However, with changes in legislation, policy and guidance, there is potential for some improvements to have been made (changes between 2000 and 2010 are summarised in Appendix B). Yet there has been little recent work evaluating EclA performance. Increasingly strong legislative protection of biodiversity, as well as increased recognition of the importance of ecology in planning guidance and improvements in professional development, warrant a study that builds on these early EclA chapter reviews.

\subsection{Use of the quantitative approach in ES research}

\subsubsection{Difficulties}

The lack of inferential statistics in the literature on this topic is partly due to the subjective nature of ES research. For example, whether an ES or EclA chapter is deemed to have met particular criteria in 
checklist-based reviews often depends on the reviewer (Põder and Lukki, 2011). In addition, each ES is subject to a different array of constraints and contexts (such as the likely controversy of the proposed development and the development type), making comparisons between ESs and assessments of changes over time less reliable. One way to overcome this problem is to use matched pairs of ESs (i.e. each ES assigned to one time period is 'matched' to an ES in another time period by development type, development size, etc.), as demonstrated by Glasson et al. (1997). Another method is to ensure the sample size (i.e. the number of ESs reviewed) is large (e.g. Ryan, 2013, p. 298).

The use of the results of previous reviews of EclA chapters to quantitatively examine changes over time also presents several difficulties. For example, some of the assessment criteria may have been slightly different in different reviews, making comparisons difficult. In addition, previous reviews may have expressed their findings as percentages of EclA chapters. If these are expressed to one or fewer decimal places, determining the actual number of EclA chapters may be less accurate (for example, $14.8 \%$ of 37 EclA chapters could be either five or six EclA chapters, depending on the rounding method used. All of these issues make the use of inferential statistics more challenging.

\subsubsection{Advantages}

However, whilst another analysis of EcIA chapters using purely descriptive statistics would be timely given the decade since the last review, it would miss an important opportunity. That opportunity is the secondary analysis of results from the earlier reviews in order to address the new question of whether there have been changes over time. There are, as described above, several issues with statistically comparing the results of previous reviews. However, whilst simple comparisons of percentages across reviews may be illustrative, a statistical analysis across reviews (whilst making attempts to minimise, and clearly stating, the limitations of such an approach) may prove more informative (Burstein, 1978). With regard to checklist-based reviews of ESs and EclA chapters, there does seem to be a legitimate research gap in the use of inferential statistics. 


\subsection{International EcIA chapter reviews}

Many countries using EIA also experience deficiencies in the information provided within EcIA chapters (e.g. Mandelik et al., 2005; Naser et al., 2008; Oscarsson and Kjellander, 2004; Samarakoon and Rowan, 2008; Wegner et al., 2005). There have also been several attempts internationally to standardise reviews of EclA chapter procedural effectiveness (e.g. Atkinson et al., 2000; Khera and Kumar, 2010; Soderman, 2005), thereby allowing inter-country comparisons. This study, whilst focused on EcIA in England, therefore has wider applicability to the international context in attempting to compare EclA chapter reviews over time, rather than spatially between countries.

\section{Method}

\subsection{EclA chapter sample}

112 ESs were obtained from a variety of sources, including the Oxford Brookes University Planning Department's Resources Centre, local authority websites, internet searches and environmental consultancies. The ESs included all relevant technical appendices. Post-consent documents, such as decision notices, planning agreements and management plans were not considered in this analysis to ensure comparability with the previous EclA chapter reviews.

To ensure that only the current status of the planning system as a whole (as opposed to, for example, simply flaws in the approach used by ecological consultants) was investigated, this review was restricted to ESs for developments that were granted planning permission (including those for which appeals against refusal or non-determination were upheld).

To avoid any potential for including ESs that had been analysed in the previous published reviews, a submission year of 2000 was used as the earliest from which the sample could be drawn. Since 1998, devolution has created subtle differences in the legislative, policy and guidance framework for EclA in England, Wales, Scotland and Northern Ireland, presenting difficulties in direct EclA comparison 
(UKELA et al., 2012). As a result, only ESs for developments within England were included. Aside from these three criteria, no further restrictions were made.

It is not possible to determine how representative this sample is of the ESs submitted and granted planning permission across England during that time period, due to the lack of a centralised EIA planning application database. However, an earlier study noted that a sample size of 100 ESs was sufficient from which to draw meaningful conclusions (DETR, 1997). Given the wide variety of sources from which ESs in this study were obtained, it is assumed that a sample of 112 can be considered to be representative. Their details can be found in Appendix A.

\subsection{Data collection}

A review of the previous EclA chapter review studies was conducted to identify those checklist questions that the different EcIA chapter reviews had in common. The previous EclA chapter reviews did not include lists of the questions asked, or the thresholds used for answering each question. As a result, the questions and how they should be answered had to be inferred from the main text of the reviews.

These questions were then used on the current sample of 112 EclA chapters (where necessary, also consulting the technical appendices and introductory chapters of the ES). Wherever possible, questions (and the range of possible answers to each question) were phrased such that the results would be as comparable as possible to those of the earlier reviews. To aid analysis, the range of possible answers to each question in the list was identified and standardised. For example, the majority of questions could be answered from amongst the following range of possible answers; 'Yes', 'No', 'Partly/Some', 'Unknown' and 'N/A' (Not Applicable). 


\subsection{Data analysis}

\subsubsection{Assumptions}

In the majority of the earlier studies, the reviewed ESs were not named (RSPB, 1995; Spellerberg and Minshull, 1992; Thompson et al., 1997; Treweek and Thompson, 1997), and so whilst an assumption is made regarding independence in the data analysis, this may not necessarily be the case. The assumption is also made that the current review's restriction to English ESs will not affect the analysis or interpretation of the results. It is also assumed that previous reviews' restrictions to ESs for particular development types will have a minor impact on the results in comparison with the large changes in legislation, policy, guidance and professional practice over the study period. For example, it might be expected that modern wind farm EclA chapters (relatively unusual in the previous EclA chapter reviews) would be more likely to include bat surveys and so could skew the fauna survey results. However, similar percentages of the wind farm and road EclA chapters reviewed in the current study conducted bat surveys. This is likely due to stronger legislation with regard to European Protected Species, and also greater recognition that roads can also have significant impacts on bats.

\subsubsection{Statistical tests}

To compare EclA chapter frequencies in answering certain questions (e.g. whether or not development size had been stated) across multiple studies, the Pearson chi square test was used. In order to ensure accuracy, the exact two-tailed P-value of the Pearson chi square test was calculated. This also enabled tests to be performed where expected cell counts were below five or where observed counts were zero (Mehta and Patel, 2010). All analyses were carried out using SPSS (IBM SPSS Statistics 19).

Use of null hypothesis significance testing is not without its problems (e.g. Cumming et al., 2007; Fidler et al., 2006; Fidler and Loftus, 2009). As a result, 95\% confidence intervals for proportions have been included in the figures. 


\subsection{Replicability study}

Commonly, ES review packages recommend that the reviews are conducted by more than one person, to reduce the effects of personal subjectivity (e.g. Lee et al., 1999). However, given the length of time required for each review, several studies have involved ES review by only one person (e.g. Canelas et al., 2005; McGrath and Bond, 1997), with a sample of the reviewed ESs being rereviewed and the results compared. The latter approach was used in this study.

To determine the replicability of the current review of $112 \mathrm{EclA}$ chapters, the first five chapters were re-reviewed (approximately one year after their initial analysis) using a separate spreadsheet. The number of identical versus different answers between the two reviews was calculated for each of the five EcIA chapters. To determine whether the level of replicability was acceptable, the alternative (one-tailed) hypothesis that the proportion of identical answers is greater than $95 \%$ was tested. A one-sample binomial test procedure in SPSS was conducted for each re-reviewed EcIA chapter.

\section{Results and discussion}

\subsection{Replicability study}

The null hypothesis that the proportion of identical answers is equal to $95 \%$ was rejected for each of the five re-reviewed EclA chapters in favour of the alternative hypothesis that the proportion of identical answers is greater than $95 \%(p<0.05)$. The study therefore shows high replicability of EclA chapter analysis.

\subsection{Comparisons with previous review studies}

A summary of the comparisons between the current EcIA chapter review and the earlier reviews can be found in Table 2. A selection of these comparisons will be explored in detail in this section. 


\subsubsection{Development sector}

A comparison between the current review and the two earlier reviews that considered ESs from multiple development sectors can be found in Fig. 1. The categories from the Thompson et al. (1997) review were taken, being the broadest of the three reviews (it is easier for narrow categories to be combined into a broader category than vice versa). Of note is the significant reduction in the percentage of ESs in the current review drawn from industrial developments, such as power stations, mineral extraction, open cast mining, landfill, and waste treatment (see Table 3 rows 1-5, respectively, for the Pearson chi square test results). This contrasts with significant increases in the percentage of ESs for wind farms, mixed developments and 'other', which included residential, business parks, park and ride facilities and railways, etc. (see Table 3 rows $6-8$, respectively, for the Pearson chi square test results).

Aside from a gradual decline in industry in the UK since the 1980s, other contributing factors are likely to include changes in policy towards mixed-use developments (e.g. University of Westminster et al., 2002) and changes in energy policy encouraging renewable electricity generation (e.g. DTI, 2003). The significant increases in the 'other' category are potentially due to a greater number of less easily classified developments being proposed, such as business parks, retail developments and park and ride facilities. 
Table 2: Summary of the changes observed over time in comparison with earlier EclA chapter reviews.

\begin{tabular}{|c|c|c|c|c|c|c|c|c|c|}
\hline \multirow[b]{2}{*}{ EclA Chapter Section } & \multirow[b]{2}{*}{ Question } & \multicolumn{6}{|c|}{ Question asked in earlier EclA chapter review? } & \multirow[b]{2}{*}{$\begin{array}{l}\text { Significant change over } \\
\text { time in comparison with } \\
\text { current review? }\end{array}$} & \multirow[b]{2}{*}{$\begin{array}{l}\text { Direction of } \\
\text { change over time }\end{array}$} \\
\hline & & $\begin{array}{c}\text { Spellerberg } \\
\text { \& Minshull } \\
1992\end{array}$ & $\begin{array}{c}\text { Treweek } \\
\text { et al. } \\
1993\end{array}$ & $\begin{array}{l}\text { RSPB } \\
1995\end{array}$ & $\begin{array}{l}\text { Thompson } \\
\text { et al. } 1997\end{array}$ & $\begin{array}{c}\text { Treweek \& } \\
\text { Thompson } \\
1997\end{array}$ & $\begin{array}{l}\text { Byron } \\
\text { et al. } \\
2000\end{array}$ & & \\
\hline General & Ecological consultancy involved in EcIA? & $x$ & $x$ & $x$ & $\checkmark$ & $x$ & $x$ & $\checkmark$ & + \\
\hline Baseline - Desk Study & Development size stated? & $x$ & $\checkmark$ & $x$ & $\checkmark$ & $x$ & $\checkmark$ & $\checkmark$ & + \\
\hline Baseline - Desk Study & Linear development length stated? & $x$ & $\checkmark$ & $x$ & $\checkmark$ & $x$ & $\checkmark$ & $\checkmark$ & + \\
\hline Baseline - Desk Study & Ecological consultation conducted? & $x$ & $x$ & $x$ & $\checkmark$ & $x$ & $x$ & $x$ & $\mathrm{~N} / \mathrm{A}$ \\
\hline Baseline - Desk Study & Natural England (or equivalent) consulted? & $x$ & $x$ & $x$ & $\checkmark$ & $x$ & $\checkmark$ & $\checkmark$ & $/$ \\
\hline Baseline - Desk Study & Wildlife Trust consulted? & $\checkmark$ & $x$ & $x$ & $\checkmark$ & $x$ & $\checkmark$ & $\checkmark$ & 1 \\
\hline Baseline - Surveys & New ecology surveys conducted? & $\checkmark$ & $\checkmark$ & $x$ & $\checkmark$ & $x$ & $\checkmark$ & $\checkmark$ & + \\
\hline Baseline - Surveys & Ecologists named? & $x$ & $x$ & $x$ & $x$ & $x$ & $\checkmark$ & $x$ & $\mathrm{~N} / \mathrm{A}$ \\
\hline Baseline - Surveys & Provision of survey methodologies & $x$ & $x$ & $x$ & $x$ & $x$ & $\checkmark$ & $x$ & $\mathrm{~N} / \mathrm{A}$ \\
\hline Baseline - Surveys & Quantitative survey results present? & $x$ & $\checkmark$ & $x$ & $x$ & $x$ & $\checkmark$ & $\checkmark$ & + \\
\hline Baseline - Surveys & Surveys conducted over more than one year? & $x$ & $x$ & $\checkmark$ & $x$ & $x$ & $x$ & $\checkmark$ & + \\
\hline Baseline - Surveys & Fauna surveys conducted? & $x$ & $x$ & $x$ & $\checkmark$ & $x$ & $x$ & $\checkmark$ & + \\
\hline Evaluation & Geographic context of habitats stated? & $x$ & $x$ & $x$ & $x$ & $x$ & $\checkmark$ & $\checkmark$ & + \\
\hline Impact Assessment & Ecological impacts considered? & $x$ & $\checkmark$ & $x$ & $x$ & $\checkmark$ & $\checkmark$ & $\checkmark$ & + \\
\hline Impact Assessment & Assessment method stated? & $x$ & $x$ & $\checkmark$ & $x$ & $x$ & $x$ & $\checkmark$ & + \\
\hline Impact Assessment & At least one impact quantified? & $x$ & $\checkmark$ & $x$ & $\checkmark$ & $x$ & $\checkmark$ & $\checkmark$ & + \\
\hline Impact Assessment & Land take quantified? & $x$ & $x$ & $x$ & $x$ & $x$ & $\checkmark$ & $\checkmark$ & - \\
\hline Impact Assessment & Area of habitat types to be lost quantified? & $x$ & $x$ & $x$ & $x$ & $x$ & $\checkmark$ & $\checkmark$ & + \\
\hline Impact Assessment & Other ecological impacts quantified? & $x$ & $x$ & $x$ & $x$ & $x$ & $\checkmark$ & $\checkmark$ & + \\
\hline Impact Assessment & Duration of ecological impacts stated? & $x$ & $x$ & $x$ & $\checkmark$ & $x$ & $x$ & $\checkmark$ & + \\
\hline Impact Assessment & Impacts stated as being direct or indirect? & $x$ & $x$ & $x$ & $\checkmark$ & $x$ & $\checkmark$ & $\checkmark$ & + \\
\hline Impact Assessment & 'Do nothing' scenario considered? & $x$ & $x$ & $\checkmark$ & $x$ & $x$ & $x$ & $x$ & $\mathrm{~N} / \mathrm{A}$ \\
\hline Mitigation & Mitigation descriptions included? & $x$ & $\checkmark$ & $x$ & $\checkmark$ & $\checkmark$ & $\checkmark$ & $\checkmark$ & + \\
\hline Mitigation & Detailed mitigation descriptions provided? & $x$ & $\checkmark$ & $x$ & $\checkmark$ & $x$ & $\checkmark$ & $\checkmark$ & + \\
\hline Mitigation & Likely success of mitigation measures stated? & $x$ & $\checkmark$ & $x$ & $\checkmark$ & $\checkmark$ & $\checkmark$ & $\checkmark$ & + \\
\hline Mitigation & Time required for mitigation effectiveness stated? & $x$ & $x$ & $x$ & $x$ & $\checkmark$ & $x$ & $\checkmark$ & + \\
\hline Mitigation & Modifications for unsuccessful mitigation proposed? & $x$ & $\checkmark$ & $x$ & $\checkmark$ & $\checkmark$ & $x$ & $x$ & $\mathrm{~N} / \mathrm{A}$ \\
\hline Mitigation & Commitment to mitigation indicated? & $x$ & $x$ & $\checkmark$ & $x$ & $x$ & $x$ & $\checkmark$ & + \\
\hline Follow-up & References to follow-up made? & $\checkmark$ & $\checkmark$ & $\checkmark$ & $\checkmark$ & $\checkmark$ & $\checkmark$ & $\checkmark$ & + \\
\hline Follow-up & Commitment to any follow-up made? & $x$ & $\checkmark$ & $\checkmark$ & $\checkmark$ & $\checkmark$ & $\checkmark$ & $\checkmark$ & + \\
\hline Follow-up & Follow-up programme provided? & $x$ & $\checkmark$ & $\checkmark$ & $x$ & $x$ & $x$ & $x$ & $\mathrm{~N} / \mathrm{A}$ \\
\hline Presentation & Designated sites maps included? & $x$ & $x$ & $x$ & $x$ & $x$ & $\checkmark$ & $x$ & $\mathrm{~N} / \mathrm{A}$ \\
\hline Presentation & Phase 1 habitat map included? & $x$ & $x$ & $x$ & $x$ & $x$ & $\checkmark$ & $\checkmark$ & + \\
\hline
\end{tabular}

$\checkmark=$ Yes; $\boldsymbol{x}=\mathrm{No} ;+=$ positive; - = negative; N/A = Not Applicable; / = variable 


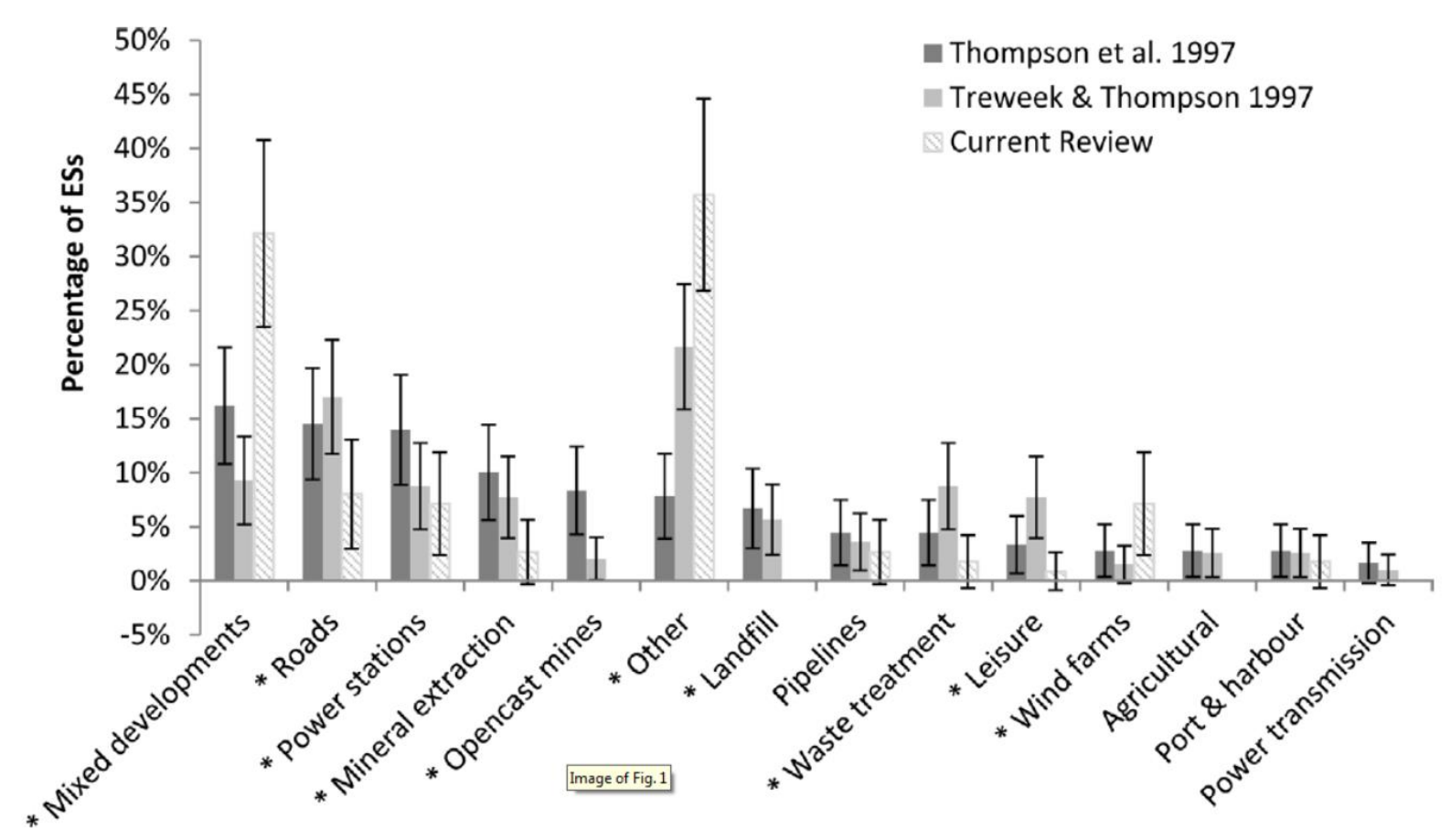

Fig. 1. Change over time in the percentage of EclA chapters in each review from different development sectors. Categories were taken from the Thompson et al. (1997) review. Developments marked with an asterisk show significant changes over time (exact $P<0.05$ ). Error bars represent $95 \%$ confidence intervals.

\subsubsection{Size}

The size of the proposed development is the most basic and easily provided information requirement of the EU's EIA Directive (Council of the European Union, 1985, as amended). It provides a broad-brush indication of the scale of the impacts that could arise from the proposed development; larger sites are potentially more likely to result in significant environmental impacts. Whilst not as specific as actual land take, overall development size is a useful indicator of potential biodiversity loss and should be included in all ESs.

Almost $12 \%$ (11.61\%) of the 112 ESs in the current review failed to state the size of the proposed development (Fig. 2). However, there has been a significant improvement over time in terms of specifying size, both for linear and non-linear developments (see Table 3 rows 9-10, respectively, for the Pearson chi square test results). The highest rates of failure to state the size of the proposed development were found in the two studies that focused on road developments (Byron et al., 2000; Treweek et al., 1993). This is likely due to roads being linear developments, for which it may be easier to state the length rather than the overall size. However, this approach could lead to 
significant underestimates of the ecological impact of such schemes, since the width of such schemes can be considerable.

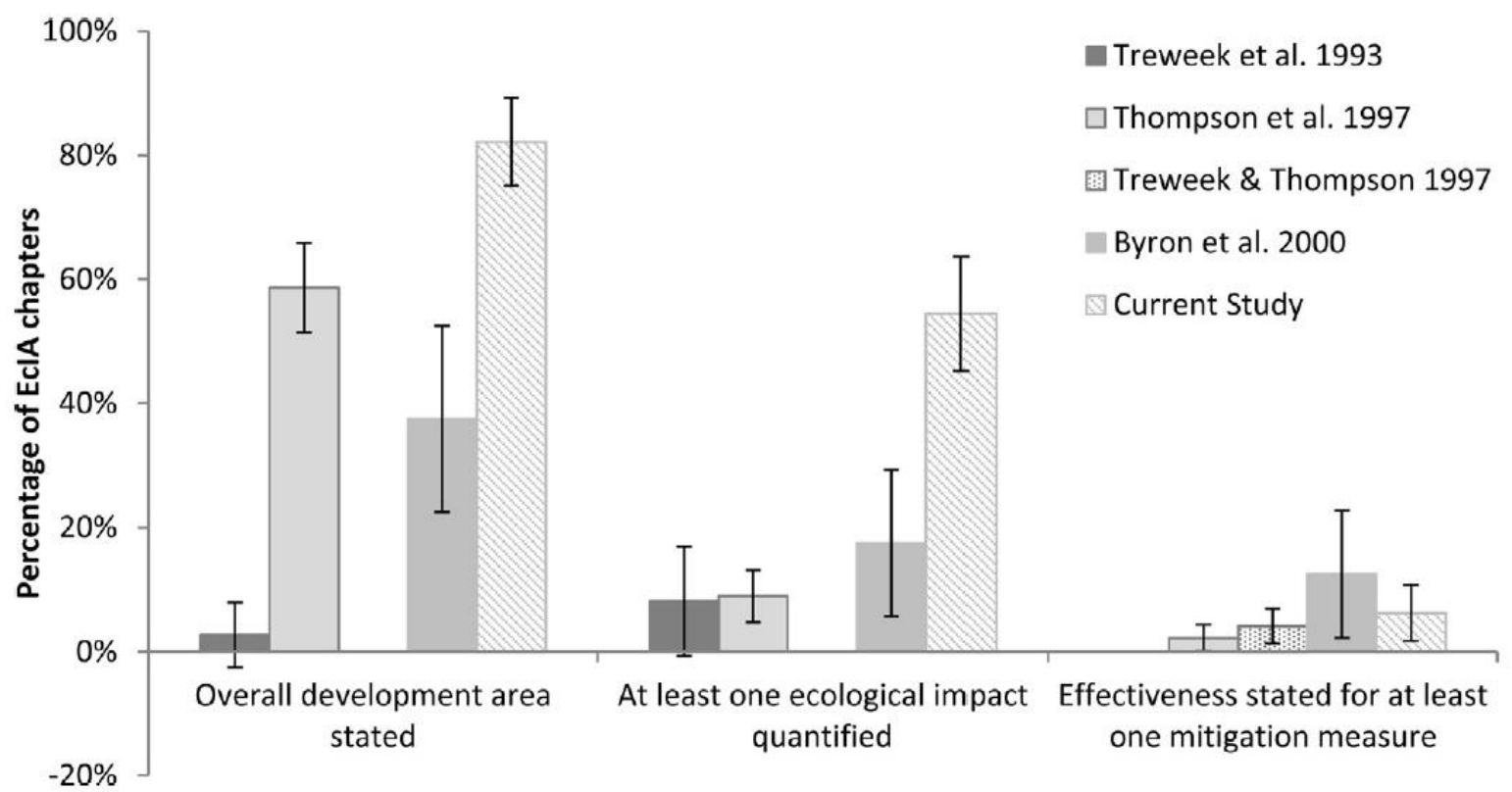

Fig. 2. Changes over time in the percentage of EclA chapters:

a) stating the overall area of the development;

b) quantifying at least one ecological impact; and

c) indicating the likely effectiveness of any of the proposed mitigation measures.

All reviews asked all three questions, with the exception of Treweek and Thompson (1997), which only asked whether mitigation effectiveness had been stated for at least one ecological impact.

Error bars represent $95 \%$ confidence intervals.

\subsubsection{Flora and fauna surveys}

Phase II vegetation surveys were conducted for 49 EclA chapters (43.75\%) and included National Vegetation Classification (NVC), river corridor, bryophyte \& lichen, hedgerow and other specific habitat surveys. Ninety (80.4\%) EclA chapters included fauna surveys, which is a significant increase on the Thompson et al. (1997) review finding of 20\% (see Table 3 row 11 for the Pearson chi square test result).

Comparison with the Byron et al. (2000) review reveals some interesting changes over time in the percentage of EclA chapters including certain survey types (Fig. 3). Surveys of the majority of vertebrates have increased, with the increases being significant for bats, amphibians, and birds (see Table 3 rows 12-14, respectively, for the Pearson chi square test results). Surveys also increased for aquatic invertebrates such as white-clawed crayfish (Austropotamobius pallipes). 
Table 3: Pearson chi square test results

\begin{tabular}{|c|c|c|c|c|c|c|}
\hline $\begin{array}{l}\text { Table row } \\
\text { number }\end{array}$ & $\begin{array}{l}\text { Section } \\
\text { number }\end{array}$ & Section title & Reference & $\begin{array}{l}\text { Pearson chi } \\
\text { square }\end{array}$ & $\begin{array}{l}\text { Degrees of } \\
\text { freedom }\end{array}$ & $\begin{array}{l}\text { Exact } P \\
\text { value }\end{array}$ \\
\hline 1 & 3.2 .1 & Development Sector & Power stations & 4.305 & 2 & 0.035 \\
\hline 2 & & & Mineral extraction & 5.501 & 2 & 0.013 \\
\hline 3 & & & Open cast mining & 15.811 & 2 & $<0.001$ \\
\hline 4 & & & Landfill & 7.470 & 2 & 0.007 \\
\hline 5 & & & Waste treatment & 7.226 & 2 & 0.011 \\
\hline 6 & & & Wind farms & 7.199 & 2 & 0.006 \\
\hline 7 & & & Mixed developments & 26.336 & 2 & $<0.001$ \\
\hline 8 & & & 'Other' & 34.464 & 2 & $<0.001$ \\
\hline 9 & 3.2 .2 & Size & Linear developments & 9.166 & 1 & 0.003 \\
\hline 10 & & & $\begin{array}{l}\text { Non-linear } \\
\text { developments }\end{array}$ & 52.132 & 3 & $<0.001$ \\
\hline 11 & 3.2 .3 & $\begin{array}{l}\text { Flora and Fauna } \\
\text { Surveys }\end{array}$ & Inclusion & 103.947 & 1 & $<0.001$ \\
\hline 12 & & & Bats & 27.934 & 1 & $<0.001$ \\
\hline 13 & & & Amphibians & 8.116 & 1 & 0.005 \\
\hline 14 & & & Birds & 13.482 & 1 & $<0.001$ \\
\hline 15 & 3.2 .4 & $\begin{array}{l}\text { Ecological Impact } \\
\text { Quantification }\end{array}$ & Inclusion & 120.772 & 3 & $<0.001$ \\
\hline 16 & & & Land take & 21.609 & 1 & $<0.001$ \\
\hline 17 & & & Habitat type loss & 7.383 & 1 & 0.010 \\
\hline 18 & & & Other impacts & 4.538 & 1 & 0.043 \\
\hline 19 & 3.2 .5 & Mitigation effectiveness & Inclusion & 11.176 & 4 & 0.003 \\
\hline 20 & 3.2 .6 & Follow-up & Inclusion & 138.973 & 6 & $<0.001$ \\
\hline 21 & & & Use of IEEM Guidelines & 0.006 & 1 & 0.939 \\
\hline
\end{tabular}

This is likely to reflect the fact that each of these groups contains species protected by EU legislation and that they are relatively straightforward to survey, with good survey and identification guides available (e.g. Bat Conservation Trust, 2007). The remaining groups appear to be characterised by a lack of European legislative protection and/or by a lack of widely available survey guidance (e.g. for fungi), potentially explaining the reduction in surveys over time (Treweek, 1995). 


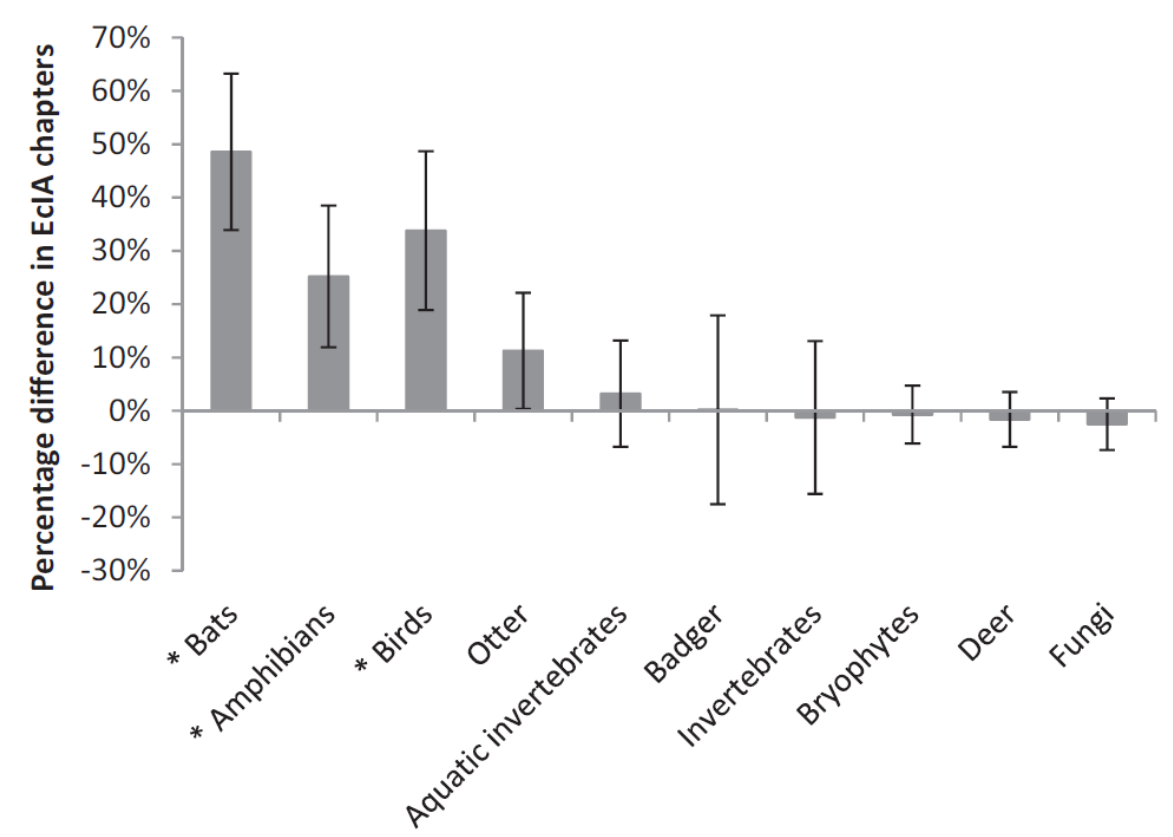

Fig. 3. Percentage difference in EclA chapters including surveys of different groups of organisms since the Byron et al. (2000) review. Survey groups marked with an asterisk have changed significantly over time (exact $P$ $<0.05)$. Error bars represent $95 \%$ confidence intervals for the percentage difference.

\subsubsection{Ecological impact quantification}

Quantifying impact predictions enables follow-up and testing to be conducted, the results of which can further scientific knowledge and inform future EclAs. Historically, impact quantification has been poor (Thompson et al., 1997; Treweek et al., 1993) but there have been significant improvements over time (Fig. 2, see Table 3 row 15 for the Pearson chi square test results).

Byron et al. (2000) noted that the improvement found in their study was primarily due to a higher percentage of EclA chapters quantifying land take (77.5\% of EclAs), which is significantly higher than in the current review. The improvement seen in the current review in impact quantification over time is due to significant progress in the quantification of habitat type loss and the quantification of other impacts (see Table 3 rows 16-18, respectively, for the Pearson chi square test results).

Whilst such an improvement in habitat type loss and other ecological impacts is welcome, it should not have come at the expense of quantifying overall land take. Relatively few $(17,15.2 \%)$ EcIA chapters quantified all of the habitat type loss expected to occur as a result of the proposed development, with 26 (23.2\%) focusing instead on important or notable habitat types. Global Positioning System (GPS) devices (particularly smartphones and tablets) are now available at 
commercially viable prices and there is a greater choice of commercially available habitat mapping software and applications. As a result, quantifying habitat type areas within a standard habitat survey visit is made cost-effective, rapid and more accurate. Habitat maps based on GPS data should therefore be the norm, rather than the exception.

\subsubsection{Mitigation effectiveness}

Few studies have examined the effectiveness of mitigation. A recent example found that whilst mitigation implementation was relatively high, effectiveness was low (Drayson and Thompson, 2013). In the absence of detailed ecological follow-up studies available to consultants, the success of mitigation measures in meeting their impact reduction or avoidance targets is uncertain. As a result, the likely success of the proposed mitigation measures should be estimated and stated. There have been significant improvements over time in the percentage of EcIA chapters indicating the likely success of their proposed mitigation measures (see Table 3 row 19 for the Pearson chi square test results). However, rates of inclusion remain very low and of the seven EclAs that indicated likely success, only one included this for every proposed mitigation measure (Fig. 2).

\subsubsection{Follow-up}

There have been significant changes over time in the inclusion of references to follow-up in EclA chapters (see Table 3 row 20 for the Pearson chi square test results). Despite follow-up being considered "good practice" in the EcIA Guidelines (IEEM, 2006 p. 48), 60.71\% of EcIA chapters still do not include any mention of follow-up. In general, however, there has been a trend of increasing percentages of EclA chapters including references to follow-up (Fig. 4). 


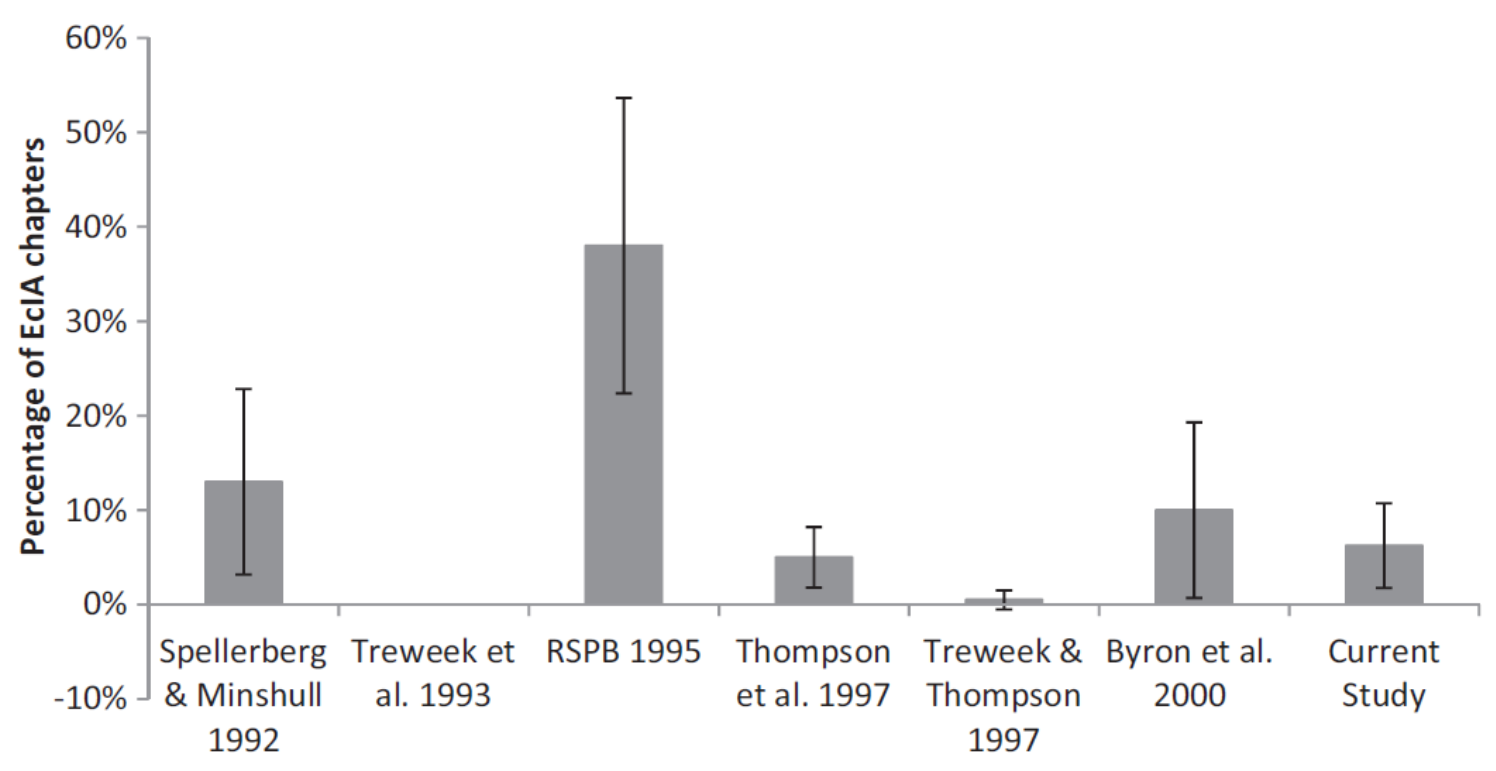

Fig. 4. Change over time in the percentage of EclA chapters including a reference to post-construction follow-up.

An interesting finding is that the current review found no significant difference in whether an EcIA included mention of monitoring whether or not the EclA stated the use of the EclA Guidelines (see Table 3 row 21 for the Pearson chi square test results). This may be because the 2006 EclA Guidelines do not place much emphasis on follow-up. Alternatively, it may be that most ESs do not mention follow-up as it is included in the post-consent documentation, such as ecological management plans. For comparability purposes, this was not assessed in the current study, as the methodologies of the previous six reviews did not include assessment of post-consent documents. The RSPB (1995) review reviewed 37 ESs, half of which were selected by RSPB staff as representative of the cases in which the RSPB were involved. It is therefore possible that early consultation with the RSPB for the latter ESs resulted in the inclusion of follow-up recommendations, which would not perhaps have otherwise been included. If this is indeed the case, this demonstrates the importance of non-statutory consultees in improving EclA chapters. 


\subsection{Recommendations from previous studies}

Previous EclA studies (i.e. not only EclA chapter reviews) have included recommendations intended to improve various aspects of the EclA process and EclA chapter information content. A summary of these recommendations is provided in Table 4. Whilst some of these recommendations are specific to EcIA (e.g. development of EclA guidelines and the earlier involvement of ecologists in project design), many can be generalised and have been recommended in studies of EIA. For example, formal review procedures have been recommended by Jones et al. (1991) and Weston (2000), whilst EIA development follow-up has been proposed by Culhane (1993) and Marshall (2005).

\section{Conclusions}

This checklist-based review of EclA chapters attempted to use inferential statistics to determine changes over time in their information content and procedural effectiveness over time. The main finding that EclA chapters from 2000 onwards have improved significantly in almost every respect in comparison with earlier EclA chapter reviews is encouraging. Of the 33 questions asked as part of the checklist review, 23 saw significant improvements post- 2000 .

However, the earlier reviews highlighted such severe information deficiencies that the progress seen in the post-2000 EclA chapters still leaves considerable scope for improvement. For example, whilst the size of the development was stated in $82 \%$ of modern EclA chapters - a major improvement on the $2.7 \%$ found by Treweek et al. (1993) - that still leaves almost a fifth of EclA chapters without this most basic and critically important piece of information.

To our knowledge, this is the only comprehensive comparison of EclA chapter reviews over time for any country. It demonstrates that whilst there are considerable difficulties in comparing studies over time, useful lessons can be drawn from the practice. This is important in the international context, where approaches to standardising EclA chapter reviews are being tested (e.g. Atkinson et al., 2000; Khera and Kumar, 2010; Soderman, 2005). 
Table 4: Summary of the recommendations made in earlier EclA studies to improve the EclA process and EcIA content.

\begin{tabular}{|c|c|c|c|c|}
\hline $\begin{array}{l}\text { Category / } \\
\text { EclA Stage }\end{array}$ & Recommendation & Study & Implemented & Comments \\
\hline \multirow[t]{2}{*}{ Regulation } & $\begin{array}{l}\text { Establish a professional } \\
\text { society }\end{array}$ & $\begin{array}{c}\text { Spellerberg } \\
\text { and Minshull } \\
(1992)\end{array}$ & $\checkmark$ & $\begin{array}{l}\text { CCIEEM was established in } 1991 \text { through } \\
\text { collaboration between its parent bodies; the British } \\
\text { Ecological Society (BES), Institute of Biology (IoB), } \\
\text { Royal Geographical Society (RGS) and British } \\
\text { Association for Nature Conservationists (BANC). } \\
\text { CCIEEM now has over 4,000 members and gained } \\
\text { Chartered status in } 2013 \text {. }\end{array}$ \\
\hline & $\begin{array}{l}\text { Develop a register of } \\
\text { biodiversity experts }\end{array}$ & $\begin{array}{l}\text { Bagri et al. } \\
\quad(1998)\end{array}$ & $\checkmark$ & $\begin{array}{l}\text { CIEEM has a Professional Directory on its website, } \\
\text { allowing developers to search for professional and } \\
\text { qualified ecologists and environmental managers } \\
\text { (CIEEM, 2012). }\end{array}$ \\
\hline \multirow[t]{2}{*}{ Guidance } & $\begin{array}{l}\text { Creation of EclA } \\
\text { chapter information } \\
\text { guidance }\end{array}$ & \begin{tabular}{|c|} 
Spellerberg \\
and Minshull \\
$(1992)$
\end{tabular} & $\checkmark$ & \multirow{2}{*}{$\begin{array}{l}\text { CIEEM published its Guidelines for Ecological } \\
\text { Impact Assessment in the United Kingdom in } 2006 .\end{array}$} \\
\hline & Develop EclA guidelines & $\begin{array}{c}\text { Bagri et al. } \\
(1998)\end{array}$ & $\checkmark$ & \\
\hline \multirow[b]{2}{*}{$\begin{array}{l}\text { Knowledge } \\
\text { Transfer }\end{array}$} & \begin{tabular}{|l|} 
Create an EclA \\
literature abstracting \\
service
\end{tabular} & \begin{tabular}{|c|} 
Spellerberg \\
and Minshull \\
$(1992)$
\end{tabular} & $x$ & $\begin{array}{l}\text { This is something that CIEEM should consider } \\
\text { establishing, particularly with Open Access journals } \\
\text { and articles becoming more prevalent. }\end{array}$ \\
\hline & $\begin{array}{l}\text { Collect and disseminate } \\
\text { 'best practice' EcIA } \\
\text { chapters }\end{array}$ & $\begin{array}{l}\text { Bagri et al. } \\
\quad(1998)\end{array}$ & $x$ & $\begin{array}{l}\text { This is something CIEEM should consider; creation } \\
\text { of a library of EcIA chapters written by its members } \\
\text { (as practised by IEMA with ESs) would be a useful } \\
\text { first step. }\end{array}$ \\
\hline $\begin{array}{l}\text { Biodiversity } \\
\text { Awareness }\end{array}$ & $\begin{array}{l}\text { Create literature to } \\
\text { publicise the } \\
\text { importance of ecology } \\
\text { in EIA for developers } \\
\text { and CPAs }\end{array}$ & $\begin{array}{c}\text { Spellerberg } \\
\text { and Minshull } \\
(1992)\end{array}$ & $\checkmark / x$ & $\begin{array}{l}\text { The importance of ecology in impact assessment } \\
\text { has increasingly been emphasised in grey (non- } \\
\text { academic) literature (e.g. IAIA, 2005; CBD } \\
\text { Conference of Parties, 2006; Byron, 2001). There is } \\
\text { a gap, however, for a more targeted and direct } \\
\text { approach to CPAs and developers as existing } \\
\text { literature tends to focus on higher level } \\
\text { organisations, such as governments. }\end{array}$ \\
\hline Design & $\begin{array}{l}\text { Ecologists should be } \\
\text { involved earlier in EIA } \\
\text { development design } \\
\text { and planning }\end{array}$ & $\begin{array}{l}\text { Treweek et } \\
\text { al. (1993) }\end{array}$ & $\checkmark / x$ & $\begin{array}{l}\text { The situation does appear to be improving, but it is } \\
\text { recognised within the environmental consultancy } \\
\text { industry that there are still many cases where } \\
\text { ecologists could and should be brought in earlier to } \\
\text { assist with the design process (Matrunola, 2007). } \\
\text { The statutory nature conservation bodies, as well } \\
\text { as CIEEM, have an important role to play in } \\
\text { ensuring that qualified and experienced ecologists } \\
\text { are consulted early in the project design process } \\
\text { (Environment Agency, 2012). Ideally, all ecologists } \\
\text { involved in the EcIA process should be CIEEM } \\
\text { members. }\end{array}$ \\
\hline $\begin{array}{l}\text { Baseline } \\
\text { Survey }\end{array}$ & $\begin{array}{l}\text { Official guidance or } \\
\text { legislation for standard } \\
\text { sampling and survey } \\
\text { methods }\end{array}$ & $\begin{array}{c}\text { Treweek } \\
\text { (1996) }\end{array}$ & $\checkmark$ & $\begin{array}{l}\text { CIEEM have created a "Sources of Survey Methods" } \\
\text { section on their website, providing references and } \\
\text { links to published survey guidance (CIEEM, 2012). } \\
\text { This gives ecologists the flexibility to choose the } \\
\text { most relevant survey methods, rather than a } \\
\text { generic survey standard. }\end{array}$ \\
\hline
\end{tabular}


Table 4: (cont.)

\begin{tabular}{|c|c|c|c|c|}
\hline \begin{tabular}{|l} 
Category / \\
EclA Stage
\end{tabular} & Recommendation & Study & Implemented & Comments \\
\hline \multirow[b]{2}{*}{ Evaluation } & $\begin{array}{l}\text { Research on the } \\
\text { evaluation of ecological } \\
\text { data and development } \\
\text { methods }\end{array}$ & $\begin{array}{c}\text { Treweek } \\
\text { (1996) }\end{array}$ & $x$ & $\begin{array}{l}\text { The EclA Guidelines specifically move away from } \\
\text { the matrix method of evaluation used in, for } \\
\text { example, the DMRB Volume } 11 \text { (Highways Agency, } \\
\text { 1992, as amended). However, there has been no } \\
\text { research conducted on the effects of the change in } \\
\text { evaluation methodology. }\end{array}$ \\
\hline & \begin{tabular}{|l|} 
Introduce an \\
'ecosystems' \\
perspective into impact \\
assessment
\end{tabular} & $\begin{array}{l}\text { Bagri et al. } \\
\quad(1998)\end{array}$ & $\checkmark / x$ & $\begin{array}{l}\text { There is increasing, though relatively recent, } \\
\text { recognition of the importance of the ecosystem } \\
\text { approach. Several studies have investigated the } \\
\text { approach from an environmental management } \\
\text { perspective (e.g. Thompson and Hearn, 2012) but } \\
\text { comparatively few have been conducted within } \\
\text { the context of EIA. This may be due to the } \\
\text { difficulties arising from their independent origins } \\
\text { (Coleby et al., 2011). }\end{array}$ \\
\hline $\begin{array}{l}\text { Impact } \\
\text { Assessment }\end{array}$ & $\begin{array}{l}\text { There should be } \\
\text { minimum requirements } \\
\text { for quantification of } \\
\text { predicted impacts }\end{array}$ & $\begin{array}{c}\text { Treweek } \\
(1996)\end{array}$ & $x$ & $\begin{array}{l}\text { The first edition of the EcIA Guidelines stated that } \\
\text { quantitative data should be provided "if possible". } \\
\text { The second edition now suggests that such data } \\
\text { could include "the amount of habitat lost, } \\
\text { percentage change to habitat area, percentage } \\
\text { decline in a species population" }\end{array}$ \\
\hline Review & $\begin{array}{l}\text { CPAs should either } \\
\text { review, or have } \\
\text { reviewed, EclA chapters } \\
\text { promptly after } \\
\text { submission }\end{array}$ & RSPB (1995) & $\checkmark / x$ & $\begin{array}{l}\text { Some CPAs subcontract EIA reviews to } \\
\text { environmental consultancies. However, this is rare } \\
\text { and with only } 41 \% \text { of CPAs employing a full-time } \\
\text { ecologist (Newey, 2012) the majority of CPAs will } \\
\text { rely on statutory and non-statutory consultees for } \\
\text { comments. }\end{array}$ \\
\hline \multirow{6}{*}{ Follow-up } & $\begin{array}{l}\text { Research on follow-up } \\
\text { ecological change }\end{array}$ & $\begin{array}{c}\text { Spellerberg } \\
\text { and Minshull } \\
(1992)\end{array}$ & $\checkmark / x$ & $\begin{array}{l}\text { Globally, there have been increasing numbers of } \\
\text { studies monitoring ecological change in response } \\
\text { to, for example, deforestation, climate change, } \\
\text { etc. However, little research has been conducted } \\
\text { on the impacts of built development on ecology. }\end{array}$ \\
\hline & $\begin{array}{l}\text { Establish a national } \\
\text { follow-up scheme for } \\
\text { EIA projects }\end{array}$ & \begin{tabular}{|c|} 
Spellerberg \\
and Minshull \\
$(1992)$ \\
\end{tabular} & $x$ & \multirow{5}{*}{$\begin{array}{l}\text { An EIA follow-up scheme that included ecology } \\
\text { would increase our knowledge of, and result in } \\
\text { improvements to, built development impact } \\
\text { prediction and mitigation measures, thereby } \\
\text { helping to prevent net loss of biodiversity. }\end{array}$} \\
\hline & $\begin{array}{l}\text { Post-project follow-up } \\
\text { of ecology should be } \\
\text { included for every } \\
\text { relevant EIA } \\
\text { development } \\
\end{array}$ & RSPB (1995) & $x$ & \\
\hline & $\begin{array}{l}\text { Introduce post- } \\
\text { development follow-up }\end{array}$ & $\begin{array}{c}\text { Treweek } \\
\text { (1996) }\end{array}$ & $x$ & \\
\hline & \begin{tabular}{|l|} 
Project impacts should \\
be formally followed-up \\
\end{tabular} & $\begin{array}{c}\text { Treweek } \\
(1996)\end{array}$ & $x$ & \\
\hline & $\begin{array}{l}\text { Introduce field-testing } \\
\text { of impact predictions }\end{array}$ & $\begin{array}{c}\text { Treweek } \\
(1996)\end{array}$ & $x$ & \\
\hline
\end{tabular}




\subsection{Auto-Critique}

The use of inferential statistics in this study is challenging for the reasons outlined in Sections 1.2.1 and 2.3.1. Indeed, the use of a quantitative approach to assessing EclA chapter quality could be questioned since decision-making within the context of EIA (e.g. scoping and screening decisions), as well as the 'science' in EIA, are not made in a purely rational context (e.g. Weston, 2000; Cashmore et al., 2004), suggesting that a qualitative approach would be more informative. In addition, checklist-based reviews present several difficulties: for example, they may not include key aspects of ESs in their review criteria (Põder and Lukki, 2011).

However, the literature of ES and EclA chapter review is dominated by the qualitative approach and descriptive statistics. Whilst this is important, the quantitative approach benefits from being systematic, replicable and generalizable. There is therefore scope for greater use of the quantitative approach, and inferential statistics in particular, to complement traditional approaches (Johnson and Onwuegbuzie, 2004).

\subsection{Recommendations and further research}

In October 2012, the European Commission proposed a series of changes to its 1985 ElA Directive (European Commission, 2012). Following amendments by the European Parliament, the new EIA Directive (2014/52/EU) entered into force in May 2014; Member States have three years to transpose and apply the legislation (Commission, 2014). Some of the changes to the EIA Directive help to address concerns raised from EIA and EclA review studies. For example, for the first time, biodiversity is mentioned directly in the legislation, together with mention of the EU's commitment to halt biodiversity loss by 2020. There is also now explicit mention of monitoring, or follow-up. In the context of this research, a particularly welcome development is a new requirement to make EIA information easy to access, ideally through "a central portal or points of access" (The European Parliament and the Council of the European Union, 2014). This should help in determining whether a sample of ESs is representative in future research, making the use of inferential statistics more 
reliable. These are positive and important legislative changes that are likely to be transposed into national legislation prior to the United Kingdom's potential exit from the European Union.

A further important change has been the release of the second edition of the EcIA Guidelines (CIEEM, 2016), a decade after the first edition was published. One of the improvements in the Guidelines is a greater acknowledgement of the importance of follow-up. Instead of a passive reliance on monitoring being included within planning conditions or legal agreements, page 28 of the Guidelines now suggests that the "EclA should identify where monitoring is required for mitigation, compensation and enhancement measures, setting out the methods to be used, the criteria for determining success/failure, appropriate timing, mechanisms for implementation, frequency and duration of monitoring, and frequency of reporting." This is welcome, as several other studies aside from the six previous EclA reviews have also recommended improved monitoring and feedback processes (e.g. Briggs and Hudson, 2013).

It will be necessary to monitor EcIA chapters written under the new EIA Directive and Guidelines, and compare their procedural effectiveness with those written under the earlier legislation and guidance. By using inferential statistics, as in the current review, it is possible to achieve this. For example, a regular (e.g. biennial) EclA chapter review could help to address questions such as:

- Will / how will changes in legislation and guidance affect the procedural effectiveness of EclA chapters?

- Is there a lag time between legislative and guidance changes being made and this being reflected in EclA chapters?

- Are there significant differences between countries or development sectors in their EclA chapter content?

- What are the main factors affecting EclA chapter content?

The answers to these questions could help inform future changes in legislation, policy and/or guidance, for example by identifying loopholes and building on best practice. 


\section{Funding}

K.D. was funded by a Nigel Groome PhD Research Studentship.

\section{Acknowledgements}

We thank Oxford Brookes University, particularly the Planning Department's Resources Centre. We also thank the anonymous reviewers for their informative and helpful comments. 
Appendix A. List of EclA Chapters Reviewed

\begin{tabular}{|c|c|c|c|}
\hline EclA name & \begin{tabular}{|l|} 
Development \\
Category
\end{tabular} & Competent Planning Authority & \begin{tabular}{|l|} 
Year of \\
Submission
\end{tabular} \\
\hline 110 Bishopsgate (Heron Tower) & Other & City of London & 2005 \\
\hline 20 Fenchurch Street & Other & City of London & 2006 \\
\hline 21 Wapping Lane & Mixed development & Tower Hamlets Borough Council & 2006 \\
\hline 30 Old Bailey & Other & City of London & 2007 \\
\hline 399 Edgware Road & Mixed development & London Borough of Brent & 2006 \\
\hline A11 Fiveways to Thetford & Roads & Secretary of State for Transport & 2008 \\
\hline A23 Handcross toWarninglid & Roads & Secretary of State for Transport & 2008 \\
\hline Addenbrookes Access Road & Roads & Cambridgeshire County Council & 2006 \\
\hline Bathside Bay & Port \& harbour & Tendring District Council & 2003 \\
\hline Battersea Power Station & Mixed development & Wandsworth Borough Council & 2009 \\
\hline Bent Farm Quarry & Mineral extraction & Cheshire East Council & 2008 \\
\hline Billingham Biomass Plant & Power stations & Stockton-on-Tees Borough Council & 2009 \\
\hline Billingham Mine Waste Management Facility & Other & Stockton-on-Tees Borough Council & 2010 \\
\hline Bishopsgate Tower & Other & City of London & 2006 \\
\hline Blackburn Meadows & Power stations & Sheffield City Council & 2008 \\
\hline Blackstone Edge & Wind farms & Barnsley Metropolitan Borough Council & 2008 \\
\hline Brent Cross & Mixed development & Barnet Borough Council & 2008 \\
\hline Broadgate & Other & City of London & 2010 \\
\hline Broom Hill Quarry & Mineral extraction & Bedfordshire County Council & 2005 \\
\hline Burton Wold Wind Farm Extension & Wind farms & Kettering Borough Council & 2007 \\
\hline Cambridge Biomedical Centre Expansion & Other & Cambridge City Council & 2006 \\
\hline Canley Regeneration Area & Mixed development & Coventry City Council & 2009 \\
\hline Charlestown Riverside & Mixed development & Salford City Council & 2010 \\
\hline Charlton Road Food Store & Other & Bath and North East Somerset & 2008 \\
\hline Coolgardie Keighley Road & Other & City of Bradford Metropolitan District Council & 2006 \\
\hline Corby Northern Orbital Road & Roads & Northamptonshire County Council & 2007 \\
\hline Docklands Light Railway & Other & Tower Hamlets Borough Council & 2006 \\
\hline Drakelow CCGT & Power stations & Secretary of State for Trade and Industry & 2005 \\
\hline East Cowes & Mixed development & Isle of Wight Council & 2006 \\
\hline East of Kettering & Mixed development & East Kettering Borough Council & 2008 \\
\hline Edingale to Drakelow Gas Pipeline & Pipelines & South Derbyshire District Council & 2008 \\
\hline Enderby Park \& Ride & Other & Leicestershire County Council & 2006 \\
\hline Essex University Research Park Extension & Mixed development & Colchester Borough Council & 2005 \\
\hline Exeter Gateway & Other & East Devon District Council & 2000 \\
\hline Exeter Science Park & Other & East Devon District Council & 2009 \\
\hline \begin{tabular}{|l|} 
Fairfield School Sports Pitches \\
\end{tabular} & Leisure & Bristol City Council & 2005 \\
\hline Fairford Lakes & Mixed development & Cotswold District Council & 2009 \\
\hline Felixstowe South Reconfiguration & Port \& harbour & Suffolk Coastal District Council & 2003 \\
\hline \begin{tabular}{|l|} 
Fullabrook Wind Farm \\
\end{tabular} & Wind farms & North Devon District Council & 2004 \\
\hline Glyndebourne Wind Turbine & Wind farms & Lewes District Council & 2007 \\
\hline Great Western Park & Mixed development & South Oxordshire District Council & 2005 \\
\hline Guest and Chrimes Remediation & Other & Rotherham Metropolitan Borough Council & 2007 \\
\hline Hartland Park & Other & Hart District Council & 2007 \\
\hline Heart of East Greenwich & Mixed development & London Borough of Greenwich & 2008 \\
\hline Heartwood Forest & Other & Forestry Commission & 2009 \\
\hline Hellrigg Wind Farm & Wind farms & Allerdale Borough Council & 2007 \\
\hline Hewlett Packard & Mixed development & South Gloucestershire District Council & 2004 \\
\hline Houghton Quarry & Mixed development & Central Bedfordshire Borough Council & 2007 \\
\hline Humber Gateway Onshore Cable & Pipelines & East Riding of Yorkshire & 2008 \\
\hline Humber Gateway Substation & Other & East Riding of Yorkshire & 2009 \\
\hline Huntsman Drive & Power stations & Stockton-on-Tees Borough Council & 2011 \\
\hline Isham Bypass & Roads & Northamptonshire County Council & 2005 \\
\hline Jeskyn's Farm & Other & Forestry Commission & 2006 \\
\hline King Alfred Sports Centre & Mixed development & Brighton \& Hove City Council & 2006 \\
\hline King's Cross Central & Mixed development & $\begin{array}{l}\text { Camden Borough Council / Islington Borough } \\
\text { Council }\end{array}$ & 2004 \\
\hline King's Cross Enhancement & Other & Camden Borough Council & 2006 \\
\hline Lakeside, Scunthorpe & Mixed development & North Lincolnshire District Council & 2003 \\
\hline
\end{tabular}




\begin{tabular}{|c|c|c|c|}
\hline EclA name & \begin{tabular}{|l} 
Development \\
Category
\end{tabular} & Competent Planning Authority & \begin{tabular}{|l}
$\begin{array}{l}\text { Year of } \\
\text { Submission }\end{array}$ \\
\end{tabular} \\
\hline Land at Hill Top Farm & Other & Cheshire County Council & 2007 \\
\hline Land West of Becklees Farm & Other & Cumbria County Council & 2010 \\
\hline Lewisham Gateway & Mixed development & London Borough of Lewisham & 2006 \\
\hline Little Cheyne Court Wind Farm & Wind farms & Shepway District Council & 2002 \\
\hline Loampit Vale & Mixed development & London Borough of Lewisham & 2009 \\
\hline London Cable Car & Other & Greenwich Borough Council & 2010 \\
\hline London Park Hotel & Mixed development & Southwark Borough Council & 2007 \\
\hline London Road, Amesbury & Other & Wiltshire County Council & 2008 \\
\hline London Wall Place & Other & City of London & 2010 \\
\hline Lower Broughton Regeneration & Mixed development & Salford City Council & 2006 \\
\hline Lower Broughton Reserved Matters & Mixed development & Salford City Council & 2008 \\
\hline Lower Clarence Wharf & Power stations & Stockton-on-Tees Borough Council & 2009 \\
\hline Marriott's Walk & Mixed development & West Oxfordshire District Council & 2006 \\
\hline Merevale Lane & Power stations & Warwickshire County Council & 2008 \\
\hline Mersey Gateway & Roads & Halton Borough Council & 2008 \\
\hline Monksmoor Farm & Mixed development & Daventry District Council & 2007 \\
\hline New Albion Wind Farm & Wind farms & Kettering Borough Council & 2009 \\
\hline North Quay Road & Power stations & East Sussex County Council & 2005 \\
\hline Northside Bridge & Roads & Cumbria County Council & 2010 \\
\hline Olympic Park Site Preparation & Other & Olympic Delivery Planning Authority & 2007 \\
\hline Pebsham HWRS & Waste treatment & East Sussex County Council & 2008 \\
\hline Polwell Lane & Mixed development & Kettering Borough Council & 2008 \\
\hline Prospect Business Park & Other & Purbeck District Council & 2007 \\
\hline Quest Pit & Other & Bedfordshire County Council & 2006 \\
\hline Ramada Deansgate & Mixed development & Manchester City Council & 2008 \\
\hline Regent's Place & Mixed development & Camden Borough Council & 2007 \\
\hline Riverbank House & Other & City of London & 2007 \\
\hline Salisbury Park \& Ride & Other & Wiltshire County Council & 2006 \\
\hline Seager Distillery & Mixed development & Lewisham Borough Council & 2008 \\
\hline Second Opening Bridge, Poole & Roads & Secretary of State for Transport & 2004 \\
\hline Shepperton Studios & Mixed development & Spelthorne Borough Council & 2004 \\
\hline South Winchester Park and Ride & Other & Hampshire County Council & 2007 \\
\hline Southall Gas Works & Mixed development & Ealing Borough Council & 2008 \\
\hline St Mary Axe & Other & City of London & 2008 \\
\hline Stone House & Mixed development & City of London & 2010 \\
\hline Teal Park & Other & North Kestevan District Council & 2009 \\
\hline Teesside Gas Processing Plant & Pipelines & Stockton-on-Tees Borough Council & 2010 \\
\hline The Avenue & Other & Derbyshire County Council & 2007 \\
\hline Town Farm Quarry & Mineral extraction & Devon County Council & 2009 \\
\hline Victoria Station Upgrade & Other & Secretary of State for Transport & 2007 \\
\hline Vopak Terminal & Power stations & Stockton-on-Tees Borough Council & 2006 \\
\hline Walton Bridge & Roads & Surrey County Council & 2007 \\
\hline Warwick Campus Extension & Other & Warwick District Council & 2009 \\
\hline Watchet East Wharf & Mixed development & West Somerset Council & 2008 \\
\hline Watermark Place & Other & City of London & 2005 \\
\hline Wave Hub & Other & Penwith District Council & 2006 \\
\hline Weirside & Waste treatment & West Berkshire District Council & 2005 \\
\hline West Quay Marina & Mixed development & Borough of Poole Council & 2008 \\
\hline Westgate Centre & Mixed development & Oxford City Council & 2006 \\
\hline White Moss Quarry & Other & Cheshire County Council & 2008 \\
\hline Whitemoor Phase 2 & Other & Cambridgeshire County Council & 2009 \\
\hline Wigmore Employment Area & Other & Luton Borough Council & 2009 \\
\hline Winchester Silver Hill & Mixed development & Winchester City Council & 2006 \\
\hline Wycombe Marsh Paper Mills & Mixed development & Wycombe District Council & 2002 \\
\hline Yelvertoft & Wind farms & Daventry District Council & 2009 \\
\hline
\end{tabular}


Appendix B. Legislative, Policy and Guidance Changes between 2000 and 2010.

\begin{tabular}{|c|c|c|c|}
\hline \begin{tabular}{|l|} 
Document \\
Type \\
\end{tabular} & Document Title and Reference & $\begin{array}{l}\text { Year Issued } \\
\text { / Amended }\end{array}$ & Relevance to EIA / EcIA \\
\hline \multirow{3}{*}{ EU Legislation } & \multirow{2}{*}{$\begin{array}{l}\text { EIA Directive (Council of the European } \\
\text { Union, 1985, as amended) }\end{array}$} & 2003 & Improved public participation and access to justice. \\
\hline & & 2009 & Expanded list of projects requiring EIA. \\
\hline & $\begin{array}{l}\text { Birds Directive (European Parliament and } \\
\text { Council of the European Union, 2009) }\end{array}$ & 2009 & Codification of the Birds Directive (1979), as amended. \\
\hline \multirow{8}{*}{ UK Legislation } & \multirow[b]{3}{*}{$\begin{array}{l}\text { EIA Regulations (HMG, 1999, as } \\
\text { amended) }\end{array}$} & 1999 & Implemented the EIA Directive and its 1997 amendment. \\
\hline & & 2006 & Incorporated the 2003 amendment to the EIA Directive. \\
\hline & & 2008 & $\begin{array}{l}\text { For outline EIA applications, additional EIA for reserved } \\
\text { matters may be required before full planning permission is } \\
\text { granted. }\end{array}$ \\
\hline & \multirow[t]{2}{*}{$\begin{array}{l}\text { Habitats Regulations (HMG, 1994, as } \\
\text { amended) }\end{array}$} & 2007 & $\begin{array}{l}\text { Increased protection of European Protected Species (EPS) } \\
\text { by removal of certain defences. }\end{array}$ \\
\hline & & 2009 & Strengthens European designated site protection. \\
\hline & Habitats Regulations (HMG, 2010) & 2010 & $\begin{array}{l}\text { Consolidated and replaced the Habitats Regulations (1994) } \\
\text { and its amendments. Ensured greater compliance with the } \\
\text { Habitats Directive (1992). }\end{array}$ \\
\hline & $\begin{array}{l}\text { Countryside and Rights of Way Act } \\
\text { (HMG, 2000) }\end{array}$ & 2000 & $\begin{array}{l}\text { Increased protection for Sites of Special Scientific Interest } \\
\text { (SSSIs) and certain wildlife. }\end{array}$ \\
\hline & $\begin{array}{l}\text { Natural Environment and Rural } \\
\text { Communities Act (HMG, 2006) }\end{array}$ & 2006 & $\begin{array}{l}\text { Formation of Natural England and strengthening of wildlife } \\
\text { and SSSI protection. The Act states that "every public } \\
\text { authority must, in exercising its functions, have regard, so } \\
\text { far as is consistent with the proper exercise of those } \\
\text { functions, to the purpose of conserving biodiversity". }\end{array}$ \\
\hline \multirow[t]{3}{*}{$\begin{array}{l}\text { International } \\
\text { Policy }\end{array}$} & $\begin{array}{l}\text { Strategic Plan for the Convention on } \\
\text { Biological Diversity (CBD Conference of } \\
\text { Parties, 2002) }\end{array}$ & 2002 & $\begin{array}{l}\text { Convention on Biological Diversity agreement to "achieve } \\
\text { by } 2010 \text { a significant reduction of the current rate of } \\
\text { biodiversity loss at the global, regional and national level". }\end{array}$ \\
\hline & $\begin{array}{l}\text { Plan of Implementation of the World } \\
\text { Summit on Sustainable Development } \\
\text { (UN, 2002) }\end{array}$ & 2002 & $\begin{array}{l}\text { Endorsed the CBD's } 2002 \text { plan to significantly reduce } \\
\text { biodiversity loss by } 2010 .\end{array}$ \\
\hline & $\begin{array}{l}\text { Aichi Targets (CBD Conference of Parties, } \\
\text { 2010) }\end{array}$ & 2010 & $\begin{array}{l}\text { Convention on Biological Diversity agreement to reduce } \\
\text { biodiversity loss to certain levels by either } 2015 \text { or 2020, } \\
\text { depending on the individual target }\end{array}$ \\
\hline \multirow[t]{5}{*}{ EU Policy } & \begin{tabular}{|l}
$\begin{array}{l}\text { Gothenburg agreement (Commission of } \\
\text { the European Communities, 2001) }\end{array}$ \\
\end{tabular} & 2001 & $\begin{array}{l}\text { EU agreement to halt the loss of biodiversity by } 2010 \text { and } \\
\text { adoption of a Sustainable Development Strategy. }\end{array}$ \\
\hline & $\begin{array}{l}\text { Sixth Environment Action Programme } \\
\text { (European Parliament and Council of the } \\
\text { European Union, 2002) }\end{array}$ & 2002 & $\begin{array}{l}\text { Endorsed the Gothenburg agreement to halt "biodiversity } \\
\text { decline with the aim to reach this objective by } 2010 \text { ". } \\
\text { Focused on "conservation" and/or "appropriate } \\
\text { restoration" of natural areas, species and habitats. }\end{array}$ \\
\hline & $\begin{array}{l}\text { Biodiversity communication (Commission } \\
\text { of the European Communities, 2006) }\end{array}$ & 2006 & $\begin{array}{l}\text { Highlighted the importance of biodiversity as part of } \\
\text { sustainable development, and set out a detailed EU } \\
\text { Biodiversity Action Plan. }\end{array}$ \\
\hline & $\begin{array}{l}\text { Renewed EU Sustainable Development } \\
\text { Strategy (Council of the European Union, } \\
\text { 2006) }\end{array}$ & 2006 & $\begin{array}{l}\text { Reiterated commitment to halt biodiversity loss by } 2010 \\
\text { and references the EU's Biodiversity Strategy as one of the } \\
\text { means to achieve this. }\end{array}$ \\
\hline & $\begin{array}{l}\text { Review of the European Union Strategy } \\
\text { for Sustainable Development } \\
\text { (Commission of the European } \\
\text { Communities, 2009b) } \\
\end{array}$ & 2009 & $\begin{array}{l}\text { Stated that "the destruction of biodiversity is continuing at } \\
\text { a worrying rate" and recommended "intensifying } \\
\text { environmental efforts for the protection of biodiversity, } \\
\text { water and other natural resources". }\end{array}$ \\
\hline UK Policy & $\begin{array}{l}\text { Planning Policy Statement } 9 \text { (ODPM, } \\
\text { 2005) }\end{array}$ & 2005 & $\begin{array}{l}\text { Outlined government objectives to promote sustainable } \\
\text { development, and conserve, enhance and restore } \\
\text { biodiversity in England. }\end{array}$ \\
\hline Guidance & $\begin{array}{l}\text { Guidelines for Ecological Impact } \\
\text { Assessment in the United Kingdom } \\
\text { (IEEM, 2006) }\end{array}$ & 2006 & $\begin{array}{l}\text { The first dedicated EclA guidance available for } \\
\text { practitioners, Competent Planning Authorities (CPAs), } \\
\text { developers and others involved with EclA. }\end{array}$ \\
\hline
\end{tabular}




\section{References}

Atkinson, S.F., Bhatia, S., Schoolmaster, F.A., Waller, W.T., 2000. Treatment of biodiversity impacts in a sample of US environmental impact statements. Impact Assess. Project Appraisal 18, 271-282.

Badr, E.-S.A., Cashmore, M., Cobb, D., 2004. The consideration of impacts upon the aquatic environment in environmental impact statements in England and Wales. J. Environ. Assess. Policy Manage. 06, 19-49.

Bagri, A., McNeely, J., Vorhies, F., 1998. Biodiversity and impact assessment. In: International Union for Conservation of Nature (IUCN) (Ed.), Biodiversity and Impact Assessment. IUCN, Christchurch, New Zealand.

Bat Conservation Trust, 2007. Bat Surveys: Good Practice Guidelines. Bat Conservation Trust, London, UK.

Briggs, S., Hudson, M.D., 2013. Determination of significance in ecological impact assessment: past change, current practice and future improvements. Environ.Impact Assess. Rev. 38, 16-25.

Burstein, L., 1978. Secondary Analysis: An Important Resource for Educational Research and Evaluation. Center for the Study of Evaluation, Los Angeles, California, USA.

Butchart, S.H.M., Walpole, M., Collen, B., van Strien, A., Scharlemann, J.P.W., Almond, R.E.A., Baillie, J.E.M., Bomhard, B., Brown, C., Bruno, J., Carpenter, K.E., Carr, G.M., Chanson, J., Chenery, A.M., Csirke, J., Davidson, N.C., Dentener, F., Foster, M., Galli, A., Galloway, J.N., Genovesi, P., Gregory, D., Hockings, M., Kapos, V., Lamarque, J.F., Leverington, F., Loh, J., McGeoch, M.A., McRae, L., Minasyan, A., Morcillo, M. H., Oldfield, T.E.E., Pauly, D., Quader, S., Revenga, C., Sauer, J.R., Skolnik, B., Spear, D., Stanwell-Smith, D., Stuart, S.N., Symes, A., Tierney, M., Tyrrell, T.D., Vie, J.C., Watson, R., 2010. Global biodiversity: indicators of recent declines. Science 328, 11641168.

Byron, H., Treweek, J., Sheate, W.R., Thompson, S., 2000. Road developments in the UK: an analysis of ecological assessment in environmental impact statements produced between 1993 and 1997. J. Environ. Plann. Manage. 43, 71-97. 
CIEEM, 2012. Professional Directory.

CIEEM, 2016. Guidelines for Ecological Impact Assessment in the UK and Ireland: Terrestrial, Freshwater and Coastal, 2nd ed. Chartered Institute of Ecology and Environmental Management, Winchester.

Canelas, L., Almansa, P., Merchan, M., Cifuentes, P., 2005. Quality of environmental impact statements in Portugal and Spain. Environ. Impact Assess. Rev. 25, 217-225.

Cashmore, M., Gwilliam, R., Morgan, R., Cobb, D., Bond, A., 2004. The interminable issue of effectiveness: substantive purposes, outcomes and research challenges in the advancement of environmental impact assessment theory. Impact Assess. Project Appraisal 22, 295-310.

CBD Conference of Parties, 2002. Strategic Plan for the Convention on Biological Diversity, In: Convention on Biological Diversity (Ed.).

CBD Conference of Parties, 2010. Strategic Plan for Biodiversity 2011-2020, In: Convention on Biological Diversity (Ed.).

Coleby, A.M., van der Horst, D., Hubacek, K., Goodier, C., Burgess, P.J., Graves, A., Lord, R., Howard, D., 2011. Environmental impact assessment, ecosystems services and the case of energy crops in England. J. Environ. Plann. Manag. 55, 369-385.

E. Commission, 2014. Environment: Impact Assessment of Projects Now Simplified.

Commission of the European Communities, 2001. Presidency Conclusions: Göteborg European Council 15 and 16 June 2001.

Commission of the European Communities, 2006. Halting the Loss of Biodiversity by 2010 - And Beyond: Sustaining Ecosystem Services for Human Well-being.

Council of the European Union, as amended, 1985. Council directive on the assessment of the effects of certain public and private projects on the environment (85/337/EEC). Off. J. Eur. Commun. $175,40-48$.

Council of the European Union, 2006. Renewed EU Sustainable Development Strategy, Brussels, Belgium. 
Culhane, P.J., 1993. Post-EIS environmental auditing: a first step to making rational environmental assessment a reality. Environ. Prof. 15, 66-75.

Cumming, G., Fidler, F., Vaux, D.L., 2007. Error bars in experimental biology. J. Cell Biol. 177, 7-11. DETR, 1997. Mitigation Measures in Environmental Statements. Department of the Environment Transport and the Regions, Rotherham, UK.

DTI, 2003. In: Department of Trade and Industry (Ed.), Our Energy Future - Creating a Low Carbon Economy. The Stationery Office, London, UK.

Drayson, K., Thompson, S., 2013. Ecological mitigation measures in English environmental impact assessment. J. Environ. Manage. 119, 103-110.

Environment Agency, 2012. Building a Better Environment: Our Role in Development and How We Can Help (consultation version). Natural England, Forestry Commission.

European Commission, 2012. Proposal for a Directive of the European Parliament and of the Council Amending Directive 2011/92/EU on the Assessment of the Effects of Certain Public and Private Projects on the Environment.

European Parliament and Council of the European Union, 2002. Decision No. 1600/2002/EC laying down the Sixth Community Environment Action Programme. Off. J. Eur. Commun. 242, 1-15. European Parliament and Council of the European Union, 2009. Directive 2009/147/EC on the conservation of wild birds. Off. J. Eur. Commun. 20, 7-25.

Fidler, F., Loftus, G.R., 2009. Why figures with error bars should replace p values. Zeitschrift für Psychologie/J. Psychol. 217, 27-37.

Fidler, F., Burgman, M.A., Cumming, G., Buttrose, R., Thomason, N., 2006. Impact of criticism of nullHypothesis significance testing on statistical reporting practices in conservation biology. impacto de la Crítica an las pruebas de significancia de hipótesis nula en las Prácticas de reporte stadístico en biología de la conservación. Conserv. Biol. 20, 1539-1544.

Foley, J.A., DeFries, R., Asner, G.P., Barford, C., Bonan, G., Carpenter, S.R., Chapin, F.S., Coe, M.T., Daily, G.C., Gibbs, H.K., Helkowski, J.H., Holloway, T., Howard, E.A., Kucharik, C.J., Monfreda, C., 
Patz, J.A., Prentice, I.C., Ramankutty, N., Snyder, P.K., 2005. Global consequences of land use. Science 309, 570-574.

Fothergill, J., 2011. The State of Environmental Impact Assessment Practice in the UK. Institute of Environmental Management \& Assessment.

Glasson, J., Heaney, D., 1993. Socio-economic impacts: the poor relations in British environmental impact statements. J. Environ. Plann. Manage. 36, 335-343.

Glasson, J., Therivel, R., Weston, J., Wilson, E., Frost, R., 1997. ElA learning from experience: changes in the quality of environmental impact statements for UK planning projects. J. Environ. Plann. Manage. 40, 451-464.

Glasson, J., 1994. EIA - only the tip of the iceberg? Town and Country Planning 63, 42-45.

Highways Agency, 1992, as amended. Design Manual for Roads and Bridges: Volume 11, London, UK. HMG, 1994. Conservation (Natural Habitats, \&c.) Regulations. Her Majesty's Stationery Office as amended.

HMG, 1999. Town and Country Planning (Environmental Impact Assessment) (England and Wales) Regulations. Her Majesty's Stationery Office as amended.

HMG, 2000. Countryside and Rights of Way Act. Her Majesty's Stationery Office.

HMG, 2006. Natural Environment and Rural Communities Act. Her Majesty's Stationery Office. HMG, 2010. The Conservation of Habitats and Species Regulations. Her Majesty's Stationery Office. IEEM, 2006. Guidelines for Ecological Impact Assessment in the United Kingdom. Institute of Ecology and Environmental Management, Winchester, UK.

Jones, C.E., Lee, N., Wood, C., 1991. UK Environmental Statements 1988-1990: An Analysis, Occasional Paper No. 29 EIA Centre. Department of Planning and Landscape, University of Manchester, Manchester.

Khera, N., Kumar, A., 2010. Inclusion of biodiversity in environmental impact assessments (EIA): a case study of selected EIA reports in India. Impact Assess. Project Appraisal 28, 189-200. Land Use Consultants, 2005. Going, Going, Gone? The Cumulative Impact of Land Development on Biodiversity in England, English Nature Research Reports. English Nature, Peterborough, UK. 
Lee, N., Colley, R., Bonde, J., Simpson, J., 1999. Reviewing the Quality of Environmental Statements and Environmental Appraisals (Occasional Paper 55). Department of Planning and Landscape, University of Manchester.

Mandelik, Y., Dayan, T., Feitelson, E., 2005. Planning for biodiversity: the role of ecological impact assessment. Conserv. Biol. 19, 1254-1261.

Marshall, R., 2005. Environmental impact assessment follow-up and its benefits for industry. Impact Assess. Project Appraisal 23, 191-196.

Matrunola, L., 2007. Mitigation Measures Proposed for Ecological Conservation: Opinions of Consultants and a Review of Environmental Statements. School of Environmental Sciences. University of East Anglia, Norwich, UK.

Maxwell, S.L., Fuller, R.A., Brooks, T.M., Watson, J.E.M., 2016. Biodiversity: the ravages of guns, nets and bulldozers. Nat. Comment 536, 143-145.

McGrath, C., Bond, A., 1997. The quality of environmental impact statements: a review of those submitted in Cork, Eire from 1988 to 1993. Project Appraisal 12, 43-52.

Mehta, C.R., Patel, N.R., 2010. IBM SPSS Exact Tests. IBM.

Millennium Ecosystem Assessment, 2005. Ecosystems and Human Well-being: Biodiversity Synthesis. World Resources Institute, Washington, DC, USA.

Morgan, R.K., 2012. Environmental impact assessment: the state of the art. Impact. Assess. Project Appraisal 30, 5-14.

Naser, H., Bythell, J., Thomason, J., 2008. Ecological assessment: an initial evaluation of the ecological input in environmental impact assessment reports in Bahrain. Impact Assess. Project Appraisal 26, 201-208.

ODPM, 2005. In: Office of the Deputy Prime Minister (Ed.), Planning Policy Statement 9: Biodiversity and Geological Conservation. Her Majesty's Stationery Office, London, UK.

Oscarsson, A., Kjellander, C., 2004. How Are Impacts on Biodiversity Analysed in EIA in Sweden? IAIA ‘04, Vancouver, Canada. 
Põder, T., Lukki, T., 2011. A critical review of checklist-based evaluation of environmental impact statements. Impact Assess. Project Appraisal 29, 27-36.

RSPB, 1995. Wildlife Impact: the Treatment of Nature Conservation in Environmental Assessment. Royal Society for the Protection of Birds, Sandy, UK.

RSPB, 2016. State of Nature 2016. RSPB, England.

Ryan, T.P., 2013. Sample Size Determination and Power. John Wiley \& Sons, Hoboken, New Jersey, USA.

Söderman, T., 2005. Treatment of biodiversity issues in Finnish environmental impact assessment. Impact Assess. Project Appraisal 23, 87-99.

Sadler, B., 1996. Environmental Assessment in a Changing World: Evaluating Practice to Improve Performance. Canadian Environmental Assessment Agency, Ottawa, Canada.

Samarakoon, M., Rowan, J., 2008. A critical review of environmental impact statements in Sri Lanka with particular reference to ecological impact assessment. Environ. Manage. 41, 441.

Spellerberg, I.F., Minshull, A., 1992. An investigation into the nature and use of ecology in environmental impact assessments. Br. Ecol. Soc. Bull. 23, 38-45.

The European Parliament and the Council of the European Union, 2014. Directive 2014/52/EU amending Directive 2011/92/EU on the assessment of the effects of certain public and private projects on the environment. Off. J. Eur. Union L124, 1-18.

Thompson, D., Hearn, K., 2012. Soils and Land Capability - Assessing the Capacity of Land to Deliver Ecosystem Services for the National Trust. In Practice: Bulletin of the Institute of Ecology and Environmental Management, 77. , pp. 17-22.

Thompson, S., Treweek, J., Thurling, D., 1997. The ecological component of environmental impact assessment: a critical review of British environmental statements. J. Environ. Plann. Manage. 40, $157-171$.

Treweek, J., Thompson, S., 1997. A review of ecological mitigation measures in UK environmental statements with respect to sustainable development. Int. J. Sustain. Dev. World Ecol. 4, 40-50. 
Treweek, J., Thompson, S., Veitch, N., Japp, C., 1993. Ecological assessment of proposed road developments: a review of environmental statements. J. Environ. Plann. Manage. 36, 295-307.

Treweek, J., 1995. Ecological impact assessment. In: Vanclay, F., Bronstein, D.A. (Eds.), Environmental and Social Impact Assessment. J. Wiley, Chichester.

Treweek, J., 1996. Ecology and environmental impact assessment. J. Appl. Ecol. 33, 191-199.

UKELA, King's College London, Cardiff University, 2012. The State of UK Environmental Law in 20112012: Is There a Case for Legislative Reform? UK Environmental Law Association, King's College London, Cardiff University's ESRC Centre for Business Relationships, Accountability, Sustainability \& Society.

University of Westminster, Llewelyn-Davies, Civic Trust, Pettersson Stafford, 2002. In: Department for Communities and Local Government (Ed.), Mixed-Use Development: Practice and Potential. University of Westminster, Llewelyn- Davies, Civic Trust, Pettersson Stafford.

Wegner, A., Moore, S.A., Bailey, J., 2005. Consideration of biodiversity in environmental impact assessment in Western Australia: practitioner perceptions. Environ. Impact Assess. Rev. 25, 143162.

Weston, J., 2000. Reviewing environmental statements: new demands for the UK's EIA procedures. Planning Practice \& Research 15, 135-142. 